\title{
Effects of Age at Unilateral Ovariectomy on Compensatory Responses of Remaining Ovary in Rabbits
}

\author{
Jiro Maniwa, Akemi Nishi, Teruo Maeda, \\ Takato Terada, and Yoshio Tsutsumi \\ Animal Reproduction Laboratory, Faculty of Applied Biological Science, \\ Hiroshima University, Higashi-Hiroshima, Hiroshima 724
}

(Accepted for publication April 20, 1989)

\begin{abstract}
Summary. Effects of age at unilateral ovariectomy (ULO) on compensatory responses of the remaining ovary were examined in rabbits. ULO was performed on 8 does for each group at 30 (group 30), 90 (group 90), 160 (group 160) and 230 days of age (group 230). Eight intact does were served as controls. Four does of each group were laparotomized and remaining ovaries were removed at first estrus (over 250 days of age). Numbers of large follicles on ovarian surface ( $\geqq 1.5 \mathrm{~mm}$ in diameter) per doe in all groups were nearly 10 and these values of ULO groups were twice as large as controls. Mean ovarian weight and volume of group 90 were the highest, and those of group 30 were second. The values in these ULO groups showed significant differences in comparison with controls. In histology of these ovaries, numbers of large, healthy follicles ( $\geqq 1 \mathrm{~mm}$ in diameter) per ovary in ULO groups were roughly double compared with those in controls. There was a tendency that the number of small, atretic antral follicles $(<1 \mathrm{~mm}$ in diameter) was increased in ULO animals operated at young age. The number of atretic antral follicles was closely correlated with ovarian weight and volume. To induce ovulation, the remaining 4 does of each group were injected with 20 IU of hCG. The numbers of corpora lutea per doe of all groups were about 10 with no significant difference among groups. These results suggest that ULO in the immature period induces marked compensatory hypertrophy after puberty and that, regardless of age at ULO, the remaining ovary in the ULO animal fulfills the function of both ovaries in the intact animal.

KEY WORDS: UNILATERAL OVARIECTOMY, COMPENSATORY OVARIAN HYPERTROPHY, OVARIAN WEIGHT, ATRETIC ANTRAL FOLLICLE.
\end{abstract}

Jpn J Anim Reprod 35, 113-118, 1989

Unilateral ovariectomy (ULO) results in compensatory hypertrophy (increase in ovarian weight) of the remaining ovary due to increase in number of corpora lutea of rats (Edgren et al., 1965), and in the follicular fluid weight of gilts (Dailey et al., 1969, 1970), sheep (Dufour et al., 1971) and heifers (Johnson et al., 1985).

In rabbits, Bond (1906) supposed that compensatory ovarian hypertrophy might occur when an unilateral ovary was removed. He considered further that this phenomenon takes place only if the operated animal is permitted to become pregnant or at least to have sexual intercourse, and that this hypertrophy may be caused by the overgrowth of ovarian stromal tissue. However,
Carmichael and Marshall (1908) noted that compensatory hypertrophy of the remaining ovary occurred in adult rabbits two to five months after ULO regardless of pregnancy or sexual intercourse. Ovulations in unilaterally ovariectomized adult rabbits, with the same number of ova as in intact animals, were reported by Asdell (1924) and Fleming et al. (1984). In our previous study, ULO in pregnant does could maintain pregnancy when considerable numbers of corpora lutea were present in the residual ovary (Tsutsumi et al., 1987).

To our knowledge, there are no reports concerning with ULO in immature rabbits, although ULO can cause a compensatory response of the 
remaining ovary in prepubertal heifers (Johnson et al., 1985), rats (Meijs-Roelofs et al., 1984) and gilts (Redmer et al., 1984, 1985, 1986). Moreover, effects of ULO in immature period on compensatory ovarian hypertrophy after puberty are obscure in most species.

Therefore, the present study was undertaken to examine effects of age at unilateral ovariectomy on compensatory hypertrophy, follicular development, and ovulation rate of remaining ovaries in rabbits.

\section{Materials and Methods}

\section{Animals}

Forty virgin, female Japanese White rabbits were used. They were reared in individual cages with food and water provided ad libitum.

\section{ULO and experimental groups}

ULO was performed on 8 does for each group at age of 30 days (group 30), 90 days (group 90), 160 days (group 160) and 230 days (group 230). The left ovary of each doe was removed by flank laparotomy under anesthesia with pentobarbitone sodium (Somnopentyl: Pitman-Moore, Washington). Eight intact does were served for a control group.

\section{Laparotomy and collection of ovaries}

Four does of each group were laparotomized at first estrus (over 250 days of age) under anesthesia with pentobarbitone sodium as judged by appearance of the vulva. The size and number of follicles of the remaining ovary in treated does or both ovaries in control does were recorded macroscopically with a rule. The excised ovaries were trimmed of extra fat and connective tissue, and their weights and volumes were measured. Ovarian volume was estimated by putting an ovary into a $10 \mathrm{ml}$ graduated cylinder with about $5 \mathrm{ml}$ sterile physiological saline. Two ovaries from four does in each group were fixed in Bouin's fluid at random for histology, and serially sectioned at $6 \mu \mathrm{m}$. All sections were stained with hematoxylin and eosin.

The remaining 4 does of each group were injected with $20 \mathrm{IU}$ human chorionic gonadotropin (hCG, Gonatropin : Teikoku-Zôki, Tokyo) at over 250 days of age, at estrus, to induce ovulation. Laparotomy was performed four days after hCG injection, and numbers of corpora lutea were counted.

\section{Ovarian histology}

All antral follicles were scanned at a magnification of 100 and were classified as undergoing atresia or healthy according to size either $\geqq 1 \mathrm{~mm}$ or $<1 \mathrm{~mm}$ in diameter. Follicles which showed pyknosis or dissolution of granulosa cells and/or shrinkage of the ovum were classified as atretic in the same way as reported by Fukunari et al. (1987). The size of the follicles was determined by measuring the diameter in the section by averaging vertical and horizontal measurements of the membrana glanulosa to obtain a diameter reading.

Statistical analysis

Data in Tables 1 and 2 were examined by analysis of variance and the significance of difference among means were determined by Duncan's multiple range test (Duncan, 1955); a probability level of $\mathrm{p}<0.05$ was considered to be statistically significant.

\section{Results}

No significant differences existed among four treated groups in mean number of large follicles ( $\geqq 1.5 \mathrm{~mm}$ in diameter) per ovary (Table 1 ). The values in ULO groups were twice those in the control group; and the number of follicles which were $\geqq 1 \mathrm{~mm}$ in diameter was two to three times as large as that in the control group. Numbers of ovulations per ovary in ULO groups were twice those of control does, also, with no significant differences among four treated groups.

Mean ovarian weights of groups 30 and 90 were significantly larger than those in controls, with the highest weight in group 90; but the difference in weights between the two groups was not significant (Table 2). Although the ovarian weights in groups 160 and 230 were slightly larger than in the control, there were no significant differences between these two groups and the control. It is also true for mean ovarian volumes in ULO groups.

In histological study (Table 3), the numbers of large, healthy follicles ( $\geqq 1 \mathrm{~mm}$ in diameter, $\mathrm{L}-\mathrm{H}$ follicles) per ovary in ULO groups were roughly double those in the control. Only in group 230, the number of large atretic follicles ( $\geqq 1 \mathrm{~mm}$ in diameter, L-A follicles) increased in comparison with those of other ULO and control groups. 
Table 1. Numbers of follicles and ovulations in remaining ovaried of unilaterally ovariectomized or intact rabbits at 250-day old

\begin{tabular}{ccccc}
\hline Group* & $\begin{array}{c}\text { No. of } \\
\text { does }\end{array}$ & \multicolumn{2}{c}{ Follicular diameter $(\mathrm{mm})$} & \multicolumn{1}{c}{$\begin{array}{c}\text { No. of } \\
\text { ovulations }\end{array}$} \\
\cline { 2 - 4 } 30 & 4 & $9.0 \pm 0.8$ & $7.8 \pm 2.2$ & $9.5 \pm 1.1$ \\
90 & 4 & $10.3 \pm 0.5$ & $6.8 \pm 1.9$ & $12.0 \pm 2.4$ \\
160 & 4 & $9.6 \pm 0.9$ & $5.3 \pm 3.3$ & $10.8 \pm 1.0$ \\
230 & 4 & $9.5 \pm 0.9$ & $8.8 \pm 2.2$ & $10.0 \pm 1.4$ \\
Control & 4 & $5.0 \pm 1.7$ & $2.6 \pm 2.0$ & $4.8 \pm 1.9$ \\
& & $(10.0 \pm 0.7)$ & $(5.5 \pm 2.3)$ & $(9.5 \pm 1.7)$ \\
\hline
\end{tabular}

Numbers and size of follicles in macroscopical observations.

Values are mean \pm S. E.

Numbers in parentheses show values per a pair of ovary in control does.

*, Numbers represent age of does at unilateral ovariectomy.

Table 2. Ovarian weight and volume of remaining ovaries in unilaterally ovariectomized and intact rabbits at 250 day-old

\begin{tabular}{cccc}
\hline Group* & No. of does & Ovarian weight $(\mathrm{mg})$ & Ovarian volume $\left(\mathrm{cm}^{3}\right)$ \\
\hline 30 & 4 & $560.6 \pm 140.2^{\mathrm{a}}$ & $0.58 \pm 0.13^{\mathrm{a}}$ \\
90 & 4 & $640.7 \pm 235.4^{\mathrm{a}}$ & $0.65 \pm 0.22^{\mathrm{a}}$ \\
160 & 4 & $498.9 \pm 136.0^{\mathrm{ab}}$ & $0.50 \pm 0.14^{\mathrm{ab}}$ \\
230 & 4 & $410.0 \pm 106.6^{\mathrm{ab}}$ & $0.38 \pm 0.08^{\mathrm{ab}}$ \\
Control & 4 & $350.6 \pm 95.8^{\mathrm{b}}$ & $0.36 \pm 0.11^{\mathrm{b}}$ \\
& & $(701.2 \pm 149.1)$ & $(0.70 \pm 0.16)$ \\
\hline
\end{tabular}

Values are mean \pm S. E.

Numbers in parentheses show total values for both ovaries in controls.

*, Numbers represent age of does at unilateral ovariectomy.

Significant differences exist among numbers with different superscripts in the same column $(p<0.05)$.

$\#$, Values in ULO are significantly small in comparison with the control value in parenthesis $(\mathrm{p}<0.05)$.

Table 3. Number of healthy or atretic antral follicles in ovaries of unilaterally ovariectomized or intact rabbits at 250 day-old

\begin{tabular}{|c|c|c|c|c|c|c|c|}
\hline \multirow{3}{*}{ Group* } & \multicolumn{6}{|c|}{ Follicular Diameter (mm) } & \multirow{3}{*}{$\begin{array}{c}\text { Total number } \\
\text { of antral } \\
\text { follicles } \\
\text { per ovary }\end{array}$} \\
\hline & \multicolumn{3}{|c|}{$\geqq 1$} & \multicolumn{3}{|c|}{$<1$} & \\
\hline & Healthy & Atretic & Total & Healthy & Atretic & Total & \\
\hline 30 & $9.0 \pm 0.0$ & $3.5 \pm 1.5$ & $12.5 \pm 1.5$ & $138.5 \pm 28.5$ & $179.0 \pm 81.0$ & $317.5 \pm 55.5$ & $330.0 \pm 58.0$ \\
\hline 90 & $9.5 \pm 1.5$ & $3.5 \pm 0.5$ & $13.0 \pm 1.0$ & $99.5 \pm 30.0$ & $158.5 \pm 113.5$ & $258.0 \pm 143.0$ & $271.0 \pm 143.0$ \\
\hline 160 & $9.0 \pm 1.0$ & $3.5 \pm 1.5$ & $12.5 \pm 2.5$ & $82.5 \pm 11.5$ & $103.5 \pm 8.5$ & $186.0 \pm 20.0$ & $198.5 \pm 22.0$ \\
\hline 230 & $8.0 \pm 3.0$ & $6.0 \pm 1.0$ & $14.0 \pm 4.0$ & $141.5 \pm 46.0$ & $24.5 \pm \quad 6.5$ & $166.0 \pm 55.0$ & $180.0 \pm 59.0$ \\
\hline Control & $4.0 \pm 3.0$ & $2.5 \pm 1.5$ & $6.5 \pm 1.5$ & $100.0 \pm 25.5$ & $17.0 \pm 7.0$ & $117.0 \pm 33.0$ & $123.5 \pm 31.5$ \\
\hline
\end{tabular}

Two ovaries were observed in each group.

Values are mean \pm S. E. per ovary.

*, Numbers represent age of does at unilateral ovariectomy. 
Effects of age at ULO were most remarkable in the numbers of small antral atretic follicles ( $<1 \mathrm{~mm}$ in diameter, $\mathrm{S}-\mathrm{A}$ follicles). There was a tendency that the number of S-A follicles was increased in ULO animals operated at young age.

The number of atretic antral follicles was closely correlated with ovarian weight $(r=0.87$; $\mathrm{p}<0.01)$ and ovarian volume $(\mathrm{r}=0.90 ; \mathrm{p}<0.01)$, but there was no correlation between ovarian weight or volume and the number of healthy antral follicles.

\section{Discussion}

Numbers of ovulations in response to hCG in remaining ovaries in ULO groups at 250 days of age were about 10, regardless of time elapsed from ULO to 250 days (Table 1). It was also the case for numbers of large follicles $(\geqq 1.5 \mathrm{~mm}$ in diameter) counted macroscopically in ovaries of non-ovulated does which had received ULO only. The number of ovulations per ovary was the same as intact animals (two ovaries). The fact that does unilaterally ovariectomized at 30 days of age ovulated about 10 ova, like those operated at other ages, suggests that age at unilateral ovariectomy does not affect on the number of large follicles and numbers of ovulations in remaining ovaries in 250-day-old.

The cause of a compensatory increase in number of follicles per ovary has been elucidated variously in different species and by several investigators-such as rescue and/or reduction of atretic follicles in rat (Welschen et al., 1978) and in sheep (Findlay and Cumming, 1977); and increase in number of small follicles proliferating to larger ones in rats (Benson et al., 1969; Greenwald, 1974), hamsters (Bast and Greenwald, 1977), and guinea pigs (Greenwald, 1974). According to Fleming et al. (1984), effects of ULO on rabbits were the following: 1) number of preovulatory follicles ( $\geqq 1 \mathrm{~mm}$ ) in the remaining ovary doubled 15 days after ULO; 2) histologically, significant changes didn't occur in the total number of antral follicles or in the proportion of atretic follicles, and compensation appeared to be the result of increased recruitment of small antral follicles into larger classes rather than a decrease in rate of atresia.

In the present study (Table 3), number of S-A follicles was increased in ULO animals operated at young age and numbers of L-H and L-A follicles in all treated groups increased. Especially in group 230, the number of L-A follicles was twice that of controls. This result of large follicles seems to be in line with the report by Fleming et al. (1984) in which proliferation of small antral follicles to larger ones was typical, rather than a decrease of atretic follicles. However, reasons for the remarkable increase of L-A follicles in group 230 and increase of S-A follicles in does unilaterally ovariectomized at young age are not apparent.

In the present study, the correlation between the number of atretic antral follicles and the ovarian weight or volume was highly significant. And the number of visible large follicles $(\geqq 1 \mathrm{~mm}$ in diameter) of ULO groups was approximately double that of controls (Table 1). One of the reasons why the ovarian weight and volume rise is that follicular fluid in these antral follicles increases, as in the case of gilts (Dailey et al., 1969, 1970), sheep (Dufour et al., 1971) and heifers (Johnson et al., 1985).

Secondary interstitial glands of the rabbit ovary arise from atretic oogonia, granulosa cells of preantral atretic follicles, and cells of the theca interna and granulosa cells of atretic antral follicles (Guraya and Greenwald, 1964). Therefore, the growth of secondary interstitial glands from atretic follicles might be responsible for the increase of ovarian weight and volume in this study. However, a relation between an increase in the ovarian weight and growth of secondary interstitial glands could not be clarified in the present histological study.

In 90-day-old rabbits, plasma FSH and ovarian estrogen levels reach adult levels, numbers of antral follicles increase, development of seocndary interstitial glands from atretic follicles commences, and rapid increase of ovarian weight occurs (de Turckheim et al., 1983; Mori and Matsumoto, 1973). Also, at 90 days, ovarian sensitivity to gonadotropin is higher than at other ages and a remarkable increase in ovarian weight and heavy degeneration of follicles can be induced by pregnant mare's serum gonadotropin (Fox et al., 1964). In the present study, the weight and volume of remaining ovaries in group 90 were the heaviest among all ULO groups (Table 2). 
This indicates that ULO performed at 90 days has a more positive effect on the remaining ovaries than that at other ages, and suggests that not only time elapsed after ULO but also age at ULO may be closely related to the compensatory hypertrophy of remaining ovaries.

In summary, these data show that ULO performed during the immature period induces compensatory hypertrophy of the remaining ovary at adult age, and that not only time elapsed after ULO, but also age at ULO affects the intensity of the compensatory hypertrophy in rabbits. Regardless of age at ULO (at least until 230 days), the remaining ovary fulfills twice the function of one ovary of an intact animal. However, further examinations of ovarian functions are needed to clarify whether the remaining ovary has an "ability" equal that of both ovaries of intact animals.

\section{Acknowledgments}

We are especially grateful to Prof. Emeritus W. J. Mellen, Department of Veterinary and Animal Sciences, University of Massachusetts, Amherst, Massachusetts, U.S.A., for kindly reviewing the manuscript. We also thank TeikokuZôki Co., Ltd., Tokyo, Japan, for supplying gonadotropin.

\section{References}

Asdell SA (1924) Some effects of unilateral ovariotomy in rabbits. $\mathrm{Br} J$ Exp Biol 1: 473-486.

Bast JD and Greenwald GS (1977) Acute and chronic elevations in serum levels of FSH after unilateral ovariectomy in the cyclic hamster. Endocrinology 100: 955-966.

Benson BS, Sorrentino S, Evans JS (1969) Increase in serum FSH following unilateral ovariectomy in the rat. Endocrinology, 84: 369-374.

Bond CJ (1906) Some points in uterine and ovarian physiology and pathology in rabbits. $\mathrm{Br}$ Med J 2: 121-127.

Carmichael ES, Marshall FHA (1908) On the occurrence of compensatory hypertrophy in the ovary. J Physiol 36: 431-434.

Dailey RA, Peters JB, First NL, Chapman AB, Casida LE (1969) Effect of unilateral ovariectomy in the Yorkshire and Poland China prepuberal gilt. J Anim Sci 28: 775-779.

Dailey RA, Cloud JG, First NL, Chapman AB, Casida
LE (1970) Response of 170-day-old prepuberal Poland China, Yorkshire and crossbred gilts to unilateral ovariectomy. J Anim Sci 31: 937-939.

de Turckheim M, Berger $\mathbf{M}$, Jean-Faucher $\mathbf{C h}$, Veyssière G, Jean Cl (1983) Changes in ovarian oestrogens and in plasma gonadotrophins in female rabbits from birth to adulthood. Acta Endocr 103: 125-130.

Dufour J, Ginther OJ, Casida LE (1971) Compensatory hypertrophy after unilateral ovariectomy and destruction of follicles in the anestrous ewe. Proc Soc Exp Biol Med 138: 1068-1072.

Duncan DB (1955) Multiple range and multiple F test. Biometrics 11: 1-42.

Edgren RA, Parlow AF, Peterson DL, Jones RG (1965) On the mechanism of ovarian hypertrophy following hemicastration in rats. Endocrinology 76: 97-102.

Findlay JK, Cumming IA (1977) The effect of unilateral ovariectomy on plasma gonadotropin levels, estrus and ovulation rate in sheep. Biol Reprod 17: $178-183$.

Fleming MW, Rhodes III RC, Dailey RA (1984) Compensatory responses after unilateral ovariectomy in rabbits. Biol Reprod 30: 82-86.

Fox RR, Cavanaugh Jr JL, Zarrow MX (1964) Influence of age on the response of the immature rabbit ovary to pregnant mare's serum (PMS). Endocrinology 75: 411-416.

Fukunari A, Maniwa J, Nagahama S, Alfonso NF, Maeda T, Tsutsumi Y (1987) Histological changes in rabbit ovaries during estrous and post-ovulatory phases after successive administrations of charcoaltreated porcine follicular fluid. J Fac Appl Biol Sci, Hiroshima Univ 26: 31-41.

Greenwald GS (1974) Role of follicle-stimulating hormone and luteinizing hormone in follicular development and ovulation. In: Handbook of Physiology, Section 7, Vol. IV, part 2. (Greep RO, Astwood EB eds.), Williams and Wilkins Co Baltimore. pp. 293-323.

Guraya SS, Greenwald GS (1964) Histochemical studies on the interstitial gland in the rabbit ovary. $\mathrm{Am}$ J Anat 114: 495-501.

Johnson SK, Smith MF, Elmore RG (1985) Effect of unilateral ovariectomy and injection of bovine follicular fluid on gonadotropin secretion and compensatory ovarian hypertrophy in prepuberal heifers. J Anim Sci 60: 1055-1060.

Mori H, Matsumoto K (1973) Development of the secondary interstitial gland in the rabbit ovary. J Anat 116: 417-430.

Redmer DA, Christenson RK, Ford JJ, Day BN (1984) Effect of unilateral ovariectomy on compensatory ovarian hypertrophy, peripheral concentrations of 
follicle-stimulating hormone and luteinizing hormone and luteinizing hormone, and ovarian venous concentrations of estradiol-17 $\beta$ in prepuberal gilts. Biol Reprod 31: 59-66.

Redmer DA, Christenson RK, Ford JJ, Day BN (1985) Effect of follicular fluid treatment on folliclestimulating hormone, luteinizing hormone and compensatory ovarian hypertrophy in prepuberal gilts. Biol Reprod 32: 111-119.

Redmer DA, Christenson RK, Ford JJ, Day BN, Goodman AL (1986) Inhibin-like activity in ovari- an venous serum after unilateral ovariectomy in prepubertal gilts. Biol Reprod 34: 357-362.

Tsutsumi Y, Yoshida Y, Samori T, Maeda T (1987) The effect of destruction of ovarian follicles in pregnant rabbits on the maintenance of pregnancy. Jpn J Anim Reprod 33: 58-63.

Welschen R, Dullaart J, de Jong FH (1978) Interrelationships between circulating levels of estradiol$17 \beta$, progesterone, FSH and LH immediately after unilateral ovariectomy in the cyclic rat. Biol Reprod 18: 421-427.

\title{
家鬼片側卵巣除去実施日齢の違いが残存卵巣の 代償性反応に及ぼす影響
}

\author{
馬庭 二郎・西 明美・前田 照夫 - 寺田 隆登・堤 義雄 \\ 広島大学生物生産学部家畜繁殖学教室
}

家鬼片側卵巣除去実施日齢の違いが残存亚巣の代償性 反応に及ぼす影響について検討した。生後30(30区)，90 (90区)，160(160区）及び 230 日齢 (230区) に各区 8 羽ず つの家鬼の左側卵巣を除去した。対照区には未処理家鬼 8 羽を用いた。250日跉に達した時点で, 外陰部の腫脹 により発情を確認し，各区の 4 羽を開腹して残存する卵 巣を摘出した。卵巣表面の直径 $1.5 \mathrm{~mm}$ 以上の 卵胞数 は, 片側卵巣除去区間では差が見られず, 卵巣 1 個当た り約10個であり，対照区の約 2 倍であった。平均卵巣重 量及び体積は90区が最大值を示し, 次いで30区であり, 両区と対照区との間には卵巣重量, 体積共に有意差が認 められた。片側卵巣除去により卵巣 1 個当たりの直径
$1 \mathrm{~mm}$ 以上の正常胞状卵胞数は, 対照区の約 2 倍に増加 した。また卵巣除去実施日龄が早い区ほど，直径 $1 \mathrm{~mm}$ 以下の閉鎖胞状卵胞数が増加する傾向を示した。卵巣重 量あるいは体積と閉鎖胞状卵胞数との間に正の高い相関 が認められた。各区の残りの 4 羽に発情確認後 hCG $20 \mathrm{IU}$ を投与し，その 4 日後に黄体数（排卵数）を確認 した。全ての区の 1 羽当たりの排卵数は約10個であり, 全区間に有意差活認められなかった。以上の結果より， 家鬼の幼若期に打ける片側卵巣除去は, 成熟後の残存卵 巣に顕著な代償性肥大をもたらし, 卵巣除去実施日齢に 関係なく, 残存卵巣は片側だけで正常家鬼の両側卵巣の 機能を十分に果たし得ることが確認された。 